\title{
HUBUNGAN PENGALAMAN PRAKTIK KERJA LAPANGAN INDUSTRI (PKLI) DENGAN KESIAPAN KERJA SISWA SESUAI STANDAR KOMPETENSI KERJA NASIONAL INDONESIA (SKKNI) KELAS XII PAKET KEAHLIAN TEKNIK KENDARAAN RINGAN SMK NEGERI 2 MEDAN T.A 2016/2017
}

\author{
Ridho Filandow Siregar dan Birsul Hapis Tambunan \\ (Tutor Bimbel Medika dan Dosen Jurusan Pendidikan Teknik Mesin)
}

\begin{abstract}
ABSTRAK
Tujuan penelitian ini adalah untuk (1) Mengetahui Tingkat Pengalaman Praktik Kerja Lapangan Industri (PKLI) Siswa Kelas XII Paket Keahlian Teknik Kendaraan Ringan SMK Negeri 2 Medan, (2) Mengetahui Tingkat Kesiapan Kerja Siswa Sesuai Standar Kompetensi Kerja Nasional Indonesia (SKKNI) Kelas XII Paket Keahlian Teknik Kendaraan Ringan SMK Negeri 2 Medan, dan (3) Mengetahui Hubungan Pengalaman PKLI dengan Kesiapan Kerja Siswa Sesuai SKKNI Kelas XII Paket Keahlian Teknik Kendaraan Ringan SMK Negeri 2 Medan. Jenis penelitian ini adalah ex-post facto. Populasi penelitian ini adalah siswa Kelas XII Paket Keahlian Teknik Kendaraan Ringan SMK Negeri 2 Medan Tahun Ajaran 2016/2017 yang berjumlah 120 siswa. Metode pengambilan data variabel Pengalaman PKLI dengan menggunakan metode dokumentasi nilai praktek kerja industri dan data variabel Kesiapan Kerja Siswa Sesuai SKKNI menggunakan Tes berupa soal pilihan berganda. Validitas instrumen penelitian dihitung menggunakan korelasi point biserial, sedangkan reliabilitas instrumennya menggunakan rumus Kudder-Ricardson 20 (KR-20). Teknik analisis data untuk menguji hipotesis menggunakan korelasi sederhana dengan taraf signifikansi 5\%. Hasil penelitian ini menunjukkan bahwa : (1) Pengalaman PKLI siswa kelas XII Paket Keahlian Teknik Kendaraan Ringan SMK Negeri 2 Medan termasuk dalam kategori tinggi yang dicapai oleh 19 siswa dengan nilai rata-rata 83,19, (2) Kesiapan Kerja Siswa Sesuai SKKNI kelas XII Paket Keahlian Teknik Kendaraan Ringan SMK Negeri 2 Medan termasuk dalam kategori tinggi yang dicapai oleh 19 siswa dengan nilai rata-rata 76,87. (3) Terdapat hubungan yang positif dan signifikan antara Pengalaman PKLI dengan Kesiapan Kerja Siswa Sesuai SKKNI kelas XII Paket Keahlian Teknik Kendaraan Ringan SMK Negeri 2 Medan. Hal ini ditunjukkan dengan nilai korelasi sebesar 0,530 dan $\left(r_{\text {hitung }} 0,530>r_{\text {tabel }}\right.$ 0.266). Berdasarkan pada tabel interpretasi, harga $r_{\text {hitung }}$ sebesar 0,530 termasuk dalam kategori sedang. Jadi terdapat kekuatan hubungan yang sedang antara Pengalaman PKLI dengan Kesiapan Kerja Siswa Sesuai SKKNI.
\end{abstract}

\section{Kata Kunci : Pengalaman, praktik, kesiapan kerja dan kompetensi}

\section{PENDAHULUAN}

Indonesia sebagai negara yang sedang berkembang dewasa ini sedang menghadapi beberapa keprihatinan nasional terutama di bidang ketenagakerjaan. Pertambahan penduduk serta angkatan kerja setiap tahunnya lebih besar dari pertambahan lapangan kerja yang dapat diciptakan. Disamping ketidakseimbangan jumlah angkatan kerja, dengan lapangan kerja, kualitas tenaga kerja pada umumnya relatif rendah dikarenakan rendahnya pendidikan dan latihan yang diperoleh. Hal ini mengakibatkan jumlah angkatan kerja yang lulus pada setiap tahunnya tidak dapat terserap sepenuhnya.

Kurangnya kualitas SDM kita membuat pelaksanaan pembangunan khususnya di bidang industri mengalami perlambatan. Untuk memenuhi hal tersebut, kesiapan kualitas daripada SDM harus ditingkatkan. Jalurnya juga turut 
dipersiapkan dengan baik melalui sistem pendidikan yang disesuaikan untuk mampu mengatasi kebutuhan SDM.

Salah satu cara mengatasi pengangguran adalah dengan meningkatkan mutu pendidikan. Melalui pendidikan yang memadai memungkinkan seseorang untuk memperoleh kesempatan kerja yang lebih baik. Sekolah Menengah Kejuruan (SMK) merupakan salah satu lembaga pendidikan yang bertangggung jawab untuk menciptakan SDM yang memiliki kemampuan, keterampilan dan keahlian, sehingga lulusannya dapat mengembangkan kinerja apabila terjun dalam dunia kerja. SMK bertujuan untuk mempersiapkan tenaga yang memiliki keterampilan dan pengetahuan sesuai dengan kebutuhan persyaratan lapangan kerja dan mampu mengembangkan potensi dirinya dalam mengadopsi dan beradaptasi dengan perkembangan teknologi.

Namun kenyataannya yang terjadi pada SMK hingga sekarang adalah adanya kesenjangan antara dunia pendidikan dan dunia kerja. Kesenjangan yang pertama berupa kemampuan lulusan yang belum sesuai dengan standar kualifikasi dunia kerja. Kesenjangan ini dapat dilihat dengan masih adanya lulusan SMK yang tidak dapat diterima di dunia kerja karena keterampilan yang dimiliki tidak sesuai dengan keterampilan yang dibutuhkan di dunia kerja. Kesenjangan yang pertama ini disebabkan dari diri siswa. Di samping itu ada pula lulusan SMK yang bekerja tidak sesuai dengan bidangnya. Kesenjangan yang kedua adalah jumlah lulusan yang tidak sesuai dengan pertumbuhan dunia kerja. Akibat ketidaksesuaian ini, angka pengangguran di Indonesia cenderung terus meningkat.

Hal ini juga terlihat pada paket keahlian teknik kendaraan ringan di sekolah SMK Negeri 2 Medan dimana dari 125 siswa yang ditamatkan untuk tahun 2015, hanya 4 orang bekerja dan 4 orang melanjut kuliah.

\section{KAJIAN PUSTAKA}

Menurut Chalpin (2006: 179), "Pengalaman adalah pengetahuan atau keterampilan yang diperoleh dari praktik atau dari luar usaha belajar". Pengalaman merupakan pengetahuan atau keterampilan yang diketahui dan dikuasai seseorang sebagai akibat dari perbuatan atau pekerjaan yang telah dilakukan sebelumnya selama jangka waktu tertentu. Seseorang dikatakan berpengalaman apabila telah memiliki tingkat penguasaan pengetahuan dan keterampilan yang relevan dan memadai sesuai dengan bidang keahliannya.

Menurut Dalyono (2005: 167), pengalaman dapat mempengaruhi fisiologi perkembangan individu yang merupakan salah satu prinsip perkembangan kesiapan (readiness) peserta didik SMK dalam mempersiapkan diri memasuki dunia kerja.

Pengalaman adalah aktivitas nyata yang jelas-jelas nyata pernah dilakukan dengan baik, pengalaman merupakan suatu tindakan dan perbuatan yang sudah pernah dilakukan di masa lampau.

Praktik Kerja Lapangan Industri (PKLI) adalah bagian dari Pendidikan Sistem Ganda (PSG) sebagai program bersama antara SMK dan Industri yang dilaksanakan di dunia usaha dan dunia industri.

Kurikulum SMK (Dikmenjur: 2008) menyebutkan : PKLI adalah pola penyelenggaraan diklat yang dikelola secara bersamaan antara SMK dengan industri/asosiasi profesi sebagai institusi pasangan (IP), mulai dari tahap perencanaan, pelaksanaan hingga evaluasi dan sertifikasi yang merupakan satu kesatuan program dengan menggunakan berbagai bentuk alternatif pelaksanaan, seperti day release, block release, dan sebagainya.

Berdasarkan teori-teori di atas yang dimaksud Pengalaman Praktik Kerja Lapangan Industri (PKLI) oleh penulis adalah pengetahuan atau keterampilan yang diketahui dan dikuasai oleh peserta didik setelah melaksanakan praktik kerja didunia usaha atau dunia industri selama jangka waktu tertentu yang ditunjukkan dengan nilai praktik yang didapat dari pihak industri/bengkel.

Menurut Kamus Besar Bahasa Indonesia, "siap" berarti "sudah bersedia" atau "sudah siap", sedangkan kesiapan menurut kamus psikologi adalah "Tingkat perkembangan dari kematangan atau kedewasaan yang menguntungkan untuk 
mempraktikkan sesuatu” (Chaplin, 2006: 419).

Dirwanto (2008: 49) juga mengemukakan pendapat bahwa, "Kesiapan kerja Siswa SMK adalah suatu kemampuan yang harus dimiliki oleh para siswa untuk dapat langsung bekerja setamat sekolah tanpa memerlukan masa penyesuaian diri yang memakan waktu dalam rangka penciptaan suatu produk atau penambahan nilai suatu sumber daya dengan hasil yang maksimal sesuai dengan target yang telah ditetapkan. Kemampuan tersebut meliputi pengetahuan, keterampilan dan sikap kerja sesuai dengan standar yang ditetapkan atau biasa disebut dengan kompetensi kerja".

Kesiapan kerja siswa dalam dunia kerja diharapkan untuk dapat mengembangkan dan menyalurkan potensi diri meliputi bakat, kemampuan, dan keterampilan melalui lapangan kerja yang dibutuhkan dalam dunia kerja.

Standar Kompetensi Kerja Nasional Indonesia (SKKNI) adalah uraian kemampuan yang mencakup pengetahuan, keterampilan dan sikap kerja minimal yang harus dimiliki seseorang untuk menduduki jabatan tertentu yang berlaku secara Nasional.

Standar tersebut adalah acuan yang dibuat oleh industri yang digunakan untuk menetapkan tingkat kemampuan yang efektif dalam perawatan dan perbaikan di bengkel otomotif.

Standar tersebut merupakan kerangka kerja yang sesuai dengan kebutuhan semua pihak yang terkait, pemerintah, industri, lembaga pelatihan dan peserta pelatihan.

Standar Kompetensi kendaraan ringan dibagi menjadi enam kelompok kompetensi. Kelompok - kelompok ini terdiri dari kompetensi-kompetensi yang berhubungan dengan bagian tertentu dari kendaraan. Enam kelompok kompetensi dibagi menjadi dua kategori utama yaitu :

1) Kompetensi Umum

Kompetensi yang umumnya dibutuhkan oleh semua orang yang bekerja pada semua sektor perawatan dan perbaikan kendaraan ringan.

2) Kompetensi Khusus
Kompetensi dibutuhkan pada area yang khusus dari perawatan dan perbaikan kendaraan ringan berdasarkan kebutuhan pekerjaan dan tempat kerja tertentu seperti : Engine, Power Train, Chasis \& Suspension, Electrical, serta Body \& Painting.

\section{METODE PENELITIAN}

Penelitian ini memiliki satu variabel bebas dan satu variabel terikat. Variabel bebas dalam penelitian ini adalah Pengalaman PKLI, dan variabel terikatnya adalah Kesiapan Kerja Siswa Sesuai SKKNI.

Dalam menentukan jumlah sampel pada penelitian ini adalah menggunakan rumus Slovin dengan taraf kesalahan $10 \%$.

Dari hasil perhitungan diperoleh 55 orang siswa yang akan diambil sebagai sampel dari kumpulan populasi.

Sehingga teknik sampling yang digunakan untuk menentukan ukuran sampel yang stratanya ditentukan menurut kelas mengunakan proportionate stratified random sampling (Sugiyono,2013:120).

Sesuai dengan tujuan penelitian ini, yaitu untuk mengetahui seberapa besar hubungan Pengalaman PKLI dengan Kesiapan Kerja Siswa Sesuai SKKNI, maka digunakan pendekatan penelitian kuantitatif dengan metode penelitian korelasi untuk mengetahui hubungan antara variabel yang akan diteliti. Sebagaimana pendapat Sukardi (2013:166), "penelitian korelasi adalah suatu penelitian yang melibatkan tindakan pengumpulan data guna menentukan, apakah ada hubungan dan tingkat hubungan antara dua variabel atau lebih".

Adapun teknik yang digunakan dalam dalam pengumpulan data dalam penelitian ini, yaitu metode dokumentasi dan tes.

Dokumentasi dalam penelitian ini digunakan untuk mengumpulkan data variabel bebas $(\mathrm{X})$ atau Pengalaman PKLI yaitu nilai hasil praktik kerja industri yang didapat dari industri/bengkel.

Metode Tes digunakan untuk mengumpulkan data variabel terikat (Y) atau Kesiapan Kerja Siswa yang disesuiakan dengan SKKNI. Adapun soal tes yang dipakai dalam penelitian ini disesuaikan 
dengan kompetensi khusus yakni pada bidang Power Train.

Instrumen yang digunakan dalam penelitian ini adalah instrumen kesiapan kerja siswa berupa tes pada bidang power train yang disesuaikan dengan SKKNI dan dokumen terhadap nilai praktik kerja lapangan industri yang diambil dari sertifikat PKLI siswa.

\section{HASIL DAN PEMBAHASAN}

\section{Hasil Penelitian}

Pengumpulan data dalam penelitian ini dengan menggunakan dokumentasi nilai PKLI dan Tes berupa soal pilihan berganda terhadap 55 siswa. Untuk mengetahui deskripsi masing-masing variabel secara rinci dapat dilihat pada uraian berikut ini :

Berdasarkan hasil analisis deskriptif yang diolah menggunakan program komputer SPSS versi 16.0, maka dapat diketahui nilai rata-rata $(\mathrm{M})=83,19$ median $(\mathrm{Me})=84,8$ modus $(\mathrm{Mo})=82,5$ dan standar deviasi $(\mathrm{SD})$ $=4,16$. Dengan demikian, untuk nilai ratarata $(\mathrm{M})=83,19$ apabila dilihat berdasarkan tabel di atas, maka nilai tersebut berada pada kategori tinggi dicapai 19 siswa $(34,55 \%)$. Data di atas menunjukkan bahwa pengalaman praktik kerja lapangan industri (PKLI) berpusat pada kategori tinggi.

Berdasarkan hasil analisis deskriptif yang diolah menggunakan program komputer SPSS versi 16.0, maka dapat diketahui nilai rata-rata $(\mathrm{M})=76,87$ median $(\mathrm{Me})=76$ modus $(\mathrm{Mo})=76$ dan standar deviasi $(\mathrm{SD})=$ 8,09 . Dengan demikian, untuk nilai rata-rata $(\mathrm{M})=76,87$ apabila dilihat berdasarkan tabel di atas, maka nilai tersebut berada pada kategori tinggi yang dicapai oleh 19 siswa $(34,55 \%)$. Data tersebut menunjukkan bahwa kecenderungan data kesiapan kerja siswa berpusat pada kategori tinggi.

Syarat normal dipenuhi jika $\chi_{\text {hitung }}^{2}$ $\chi_{\text {tabel dan taraf yang dipakai adalah taraf }}^{2}$ signifikan $5 \%$. Alat uji yang digunakan dalam penelitian ini adalah Chi Kuadrat dengan proses penghitungan menggunakan bantuan SPSS 16.0, sehingga hasilnya dapat dilihat pada tabel.

\begin{tabular}{|l|l|l|l|l|}
\hline Variabel & Df & $\chi_{\text {hitung }}^{2}$ & $\chi_{\text {tabel }}^{2}$ & Kesimpulan \\
\hline
\end{tabular}

\begin{tabular}{|c|c|c|c|c|}
\hline $\mathrm{X}$ & 31 & 18,89 & 43,77 & Normal \\
\hline $\mathrm{Y}$ & 8 & 12,58 & 15,50 & Normal \\
\hline
\end{tabular}

Dari tabel di atas, dapat terlihat hasil uji normalitas data setiap variabel penelitian diperoleh $\chi_{\text {hitung }}^{2}<\chi_{\text {tabel }}^{2}$ pada taraf signifikan $5 \%$. Dengan demikian dapat disimpulkan bahwa data variabel Pengalaman PKLI atau Variabel (X) dan Kesiapan Kerja Siswa Sesuai SKKNI atau Variabel (Y) berdasarkan chi-kuadrat adalah berdistribusi Normal.

Uji linieritas dapat diketahui dengan menggunakan uji $F$. Hasil dari $F_{\text {hitung }}$ dikonsultasikan dengan $F_{\text {tabel }}$. Apabila $F_{\text {hitung }}$ $<\mathrm{F}_{\text {tabel}}$, maka sifat hubungannya linier. Hasil uji linearitas hubungan dapat dilihat pada tabel.

\begin{tabular}{|c|c|c|c|c|c|}
\hline & Sum of Squares & df & Mean Square & $\mathrm{F}$ & Sig. \\
\hline Between Groups & 2790.109 & 3 & 90.004 & 2.753 & .007 \\
\hline Within Groups & 752.000 & 2 & 32.696 & & \\
\hline Total & 3542.109 & 5. & & & \\
\hline
\end{tabular}

Berdasarkan tabel di atas, nilai $\mathrm{F}_{\text {hitung }}$ hubungan variabel pengalaman PKLI dengan kesiapan kerja siswa sesuai SKKNI adalah $2,753<F_{\text {tabel }}(4,02)$, sehingga dapat disimpulkan bahwa hubungan variabel pengalaman PKLI dengan kesiapan kerja siswa sesuai SKKNI bersifat LINIER.

Berdasarkan koefisien korelasi (rxy) yang dihasilkan dari output SPSS versi 16.0 menunjukkan bahwa korelasi antara variabel pengalaman praktik kerja lapangan industri (X) dengan kesiapan kerja siswa sesuai standar kompetensi kerja nasional Indonesia (Y) besarnya adalah 0,530. Hubungan yang dicari tersebut berlaku untuk sampel saja sehingga harus dilakukan uji signifikansi dengan cara mengkonsultasikan $r_{\text {hitung }}$ dengan $\mathrm{r}_{\text {tabel }}$ pada taraf signifikansi $5 \%$ dimana $\mathrm{N}=$ 55 sebesar 0,266. Jika $r_{\text {hitung }}$ lebih kecil dari $\mathrm{r}_{\text {tabel}}$, maka disimpulkan hipotesis $\mathrm{H} 0$ ditolak, sebaliknya apabila $r_{\text {hitung }}$ lebih besar dari $r_{\text {tabel }}$ maka disimpulkan hipotesis $\mathrm{Ha}$ diterima. Maka dapat disimpulkan bahwa terdapat hubungan yang positif dan sangat signifikan antara Pengalaman PKLI dengan Kesiapan 
Kerja Siswa sesuai SKKNI. Hal ini berarti HO ditolak dan Ha diterima, sehingga dapat disimpulkan bahwa "Terdapat Hubungan Yang Positif dan Signifikan Antara Pengalaman Praktek Kerja Lapangan Industri (PKLI) Dengan Kesiapan Kerja Siswa Sesuai Standar Kompetensi Kerja Nasional Indonesia (SKKNI) Kelas XII Paket Keahlian Teknik Kendaraan Ringan SMK Negeri 2 Medan".

\section{Pembahasan}

Pengalaman praktik kerja lapangan industri (PKLI) adalah hasil atau pencapaian pengetahuan yang dicapai selama proses belajar mengajar praktek kerja industri yang ditunjukkan dengan nilai praktek dari pihak industri. Tujuan dari praktek kerja lapangan industri adalah memberikan pengalaman nyata kepada siswa tentang apa yang dilakukan di industri, memahami metode yang dipakai di dunia kerja dan membandingkan materi yang diperoleh di sekolah dengan di industri. Praktek kerja lapangan sebagai salah satu metode yang memberikan pengalaman nyata kepada siswa untuk mengetahui bidang kerja yang sebenarnya dan akan memberikan manfaat baik dalam meningkatkan penguasaan kognitif, afektif dan psikomotorik.

Pihak sekolah khususnya guru perlu meningkatkan kualitas penyelenggaraan praktek industri, antara lain dengan memberikan motivasi dan pemantauan secara rutin kepada siswa yang melaksanakan praktek industri.

Dengan melakukan pemantauan
secara rutin diharapkan siswa akan melaksanakan praktek industri dengan sungguh - sungguh, sehingga pengalaman praktek industri siswa akan menjadi efektif dan bermanfaat, dengan demikian kesiapan kerja siswa pun akan menjadi tinggi. Selain itu, perlu dipertimbangkan pelaksanaan kegiatan praktek industri bagi siswa.

Kesiapan kerja mempunyai arti bahwa suatu kemantapan yang dimiliki seseorang untuk menyelesaikan suatu pekerjaan dengan sikap tenang tanpa rasa emosi, rasa percaya diri serta mempunyai pertimbangan-pertimbangan yang logis sehingga tidak mengalami hambatan.
Kesiapan kerja siswa selain dipengaruhi oleh faktor pengalaman praktek kerja industri juga dipengaruhi faktor-faktor penunjang lainnya. Faktor lain yang dapat mempengaruhi prestasi belajar meliputi faktor internal berupa aspek jasmani (struktur tubuh dan panca indra) dan aspek psikologis lainnya (kecerdasan, bakat, minat, dan kecakapan), serta faktor eksternal berupa lingkungan keluarga, lingkungan sekolah, dan lingkungan bengkel. Selain itu tingkat kesiapan kerja siswa juga dapat disebabkan oleh proses belajar mengajar yang kurang efektif serta kurangnya sarana dan prasarana untuk kegiatan belajar mengajar siswa sehingga dapat menyebabkan tingkat pengetahuan siswa menurun dan mempengaruhi kesiapan siswa dalam menghadapi dunia kerja.

Kesiapan kerja sangat berpengaruh terhadap psikologis siswa, apabila siswa telah mempunyai kesiapan yang kuat siswa tersebut akan lebih merasa percaya diri dalam menghadapi tantangan tetapi apabila kesiapan siswa masih rendah maka siswa akan lebih cenderung minder dalam menghadapi tantangan. Untuk itu perlu adanya upaya dari pihak sekolah, khususnya guru untuk selalu memberikan motivasi, bimbingan, informasi, penyediaan fasilitas praktik yang lebih lengkap, pengkajian kembali terhadap kurikulum yang digunakan, maupun pengetahuan tentang otomotif yang dibutuhkan oleh dunia kerja. Dengan demikian semakin banyak pengetahuan yang diperoleh, maka akan dapat meningkatkan kesiapan kerja siswa untuk bekerja di industri.

Perhitungan korelasi antara pengalaman PKLI dengan kesiapan kerja siswa sesuai SKKNI menunjukkan bahwa korelasi yang terjadi adalah korelasi positif, jadi apabila pengalaman praktek kerja lapangan industri siswa semakin tinggi maka tingkat kesiapan kerja siswa semakin tinggi pula. Dengan demikian diharapkan pihak sekolah khususnya guru dapat lebih meningkatkan pengalaman dan pengetahuan praktek industri siswa dengan cara memberikan motivasi kepada siswa, memberikan pemantauan secara rutin kepada siswa yang sedang melaksanakan praktek 
industri, dengan melakukan pemantauan secara rutin diharapkan siswa akan melaksanakan praktek industri dengan sungguh - sungguh dan memberikan bekal materi yang cukup untuk melaksanakan praktek industri. Praktek kerja industri merupakan aspek utama dalam membentuk siswa untuk bisa terampil dalam menghadapi dunia kerja.

Kegiatan praktek kerja industri ini memungkinkan siswa untuk melakukan suatu kegiatan yang sesuai dengan jenis, macam dan situasi kerja yang sesungguhnya. Dengan kegiatan ini siswa telah terlatih atau terkondisi dengan lingkungan industri yang sesungguhnya sehingga siswa akan mempunyai kemampuan kerja sesuai dengan kemampuan praktek yang dibutuhkan oleh industri. Dalam melaksanakan praktek kerja industri masing-masing siswa memiliki keterampilan atau kemampuan yang beragam, ada yang tinggi dan ada yang rendah sehingga prestasi yang diraihnyapun sangat beragam. Tinggi rendahnya pengalaman praktek kerja industri siswa menunjukkan tinggi rendahnya penguasaan terhadap pengetahuan dan keterampilan praktek yang diajarkan.

Dalam melaksanakan praktek kerja industri masing-masing siswa memiliki keterampilan atau kemampuan yang beragam, ada yang tinggi dan ada yang rendah sehingga prestasi yang diraihnyapun sangat beragam. Tinggi rendahnya pengalaman praktek kerja industri siswa menunjukkan tinggi rendahnya penguasaan terhadap pengetahuan dan keterampilan praktek yang diajarkan, sehingga tingkat pengetahuan yang dimiliki siswa akan sangat mempengaruhi tingkat kesiapan kerja siswa karena berhubungan dengan tingkat pengetahuan yang dimiliki oleh siswa.

\section{KESIMPULAN}

Berdasarkan hasil penelitian dan pembahasan yang dikemukakan di atas, maka dapat disimpulkan sebagai berikut: Pengalaman PKLI kelas XII Teknik Kendaraan Ringan termasuk dalam kategori sangat tinggi yang dicapai oleh 27 siswa dengan nilai rata-rata 83,19, (2) Kesiapan kerja siswa kelas XII Teknik Kendaraan
Ringan termasuk dalam kategori tinggi yang dicapai oleh 18 siswa $(34,55 \%)$, (3) Terdapat hubungan yang positif dan signifikan antara pengalaman PKLI dengan kesiapan kerja siswa sesuai SKKNI kelas XII Paket Keahlian Teknik Kendaraan Ringan SMK Negeri 2 Medan. Hal ini ditunjukkan dengan korelasi antara variabel pengalaman praktek kerja industri (X) dengan kesiapan kerja siswa (Y) besarnya adalah 0,410 dan bernilai positif. Hasil ini menunjukkan bahwa $\left(\mathrm{r}_{\text {hitung }}\right.$ $\left.0,530>r_{\text {tabel }} 0,266\right)$ sehingga dapat dikatakan signifikan. Berdasarkan pada tabel interpretasi, harga $r_{\text {hitung }}$ sebesar 0,530 apabila diinterpretasikan berada pada interval 0,40 - 0,599 dan termasuk dalam kategori sedang. Jadi terdapat kekuatan hubungan yang sedang antara pengalaman PKLI dengan kesiapan kerja siswa sesuai SKKNI.

Berdasarkan hasil penelitian dan kesimpulan di atas, maka dapat diberikan saran-saran sebagi berikut: (1) Kesiapan Kerja Siswa Kelas XII Teknik Kendaraan Ringan SMK Negeri 2 Medan berada dalam kategori tinggi. Hal ini perlu dipertahankan dengan hal - hal yang mendukung, misalnya dengan adanya upaya dari pihak sekolah, khususnya guru untuk selalu memberikan motivasi, bimbingan, informasi, penyediaan fasilitas praktik yang lebih lengkap, pengkajian kembali terhadap kurikulum yang digunakan, maupun pengetahuan tentang otomotif yang dibutuhkan oleh dunia kerja. Dengan demikian semakin banyak pengetahuan yang diperoleh, maka akan dapat meningkatkan kesiapan kerja siswa untuk bekerja di industry, dan (2) Perlu dipertimbangkan pelaksanaan kegiatan praktik industri bagi siswa. Kegiatan praktik industri hendaknya berjalan dengan efektif sehingga betul - betul memberikan pengalaman kepada siswa untuk memasuki dunia kerja atau dunia industri yang sesungguhnya.

\section{DAFTAR PUSTAKA}

Anoraga, Panji. 2009. Psikologi Kerja. Jakarta: Rineka Cipta.

Arikunto, Suharsimi. 2006.Prosedur Penelitian Suatu Pendekatan 
Praktik, Penerbit Rineka Cipta Tim Penyusun Kamus Pusat Bahasa. 2007. Jakarta.

Kamus Besar Bahasa Indonesia.

Arikunto, Suharsimi. 2010. Manajemen

Penelitian. Jakarta: Rineka Cipta.

Jakarta : Balai Pustaka.

Arikunto, Suharsimi. 2013. Prosedur

Uzer Usman, Moh. 1995. Upaya Optimalisasi Kegiatan Belajar Penelitian Suatu Pendekatan Praktek. Jakarta : Rineka Cipta

Chalpin J. P. 2006. Kamus Lengkap Psikologi (Terjemahan Kartini Kartono). Jakarta: PT Raja Grafindo Persada.

Dali, Gulo. 2003. Kamus Psikologi. Bandung: Tonis.

Dalyono. 2005. Psikologi Pendidikan. Jakarta: Rineka Cipta.

Dikmenjur. 2008. Pedoman Pelaksanaan Prakerin. Jakarta: Direktorat Pembinaan Sekolah Menengah Kejuruan, Depdiknas.Toyota Service Training. 2003. Team 21. Jakarta: Astra Motor.

Dirwanto. 2008. Analisis Faktor-faktor yang Mempengaruhi Kesiapan Kerja Siswa SMK Ma'arif NU Kesesi Kabupaten Pekalongan Tahun Pelajaran 2007/2008. Tesis. Universitas Sebelas Maret.

Hadi, Sutrisno. 2006. Metodologi Research 1, 2, 3. Yogyakarta: Andi Offset.

Hamalik, Oemar. 2007. Pengembangan SDM Pelatihan Ketenagakerjaan Pendidikan Terpadu. Jakarta: PT Bumi Aksara.

James P. Chaplin. 2000. Kamus Lengkap Psikologi. Jakarta: PT Raja Grafindo

SMK Gajah Mada Bandar Lampung. 2011. Buku Panduan Praktik Kerja Industri. Bandar Lampung: SMK Gajah Mada Bandar Lampung.

Slamet Widodo. 2004. Metodologi Penelitian. Surakarta : Universitas Sebelas Maret Press.

Sugiyono. 2010. Metode Penelitian Pendidikan (Pendekatan Kuantitatif Kualitatif dan R \& D). Bandung. Alfabeta.

Sukardi, Dewa Ketut. 1993. Psikologi Pemilihan Karir. Jakarta: Rineka Cipta.

Sri Pangestu. 1991. Kesiapan Mental Kerja Para SMKK Negeri Yogyakarta. Yogyakarta: FKIP IKIP. 